\title{
The Subtype-2 ( $\left.\mathrm{AT}_{2}\right)$ Angiotensin Receptor Regulates Renal Cyclic Guanosine 3', 5'-Monophosphate and $\mathrm{AT}_{1}$ Receptor-mediated Prostaglandin $\mathrm{E}_{2}$ Production in Conscious Rats
}

\author{
Helmy M. Siragy and Robert M. Carey \\ Department of Medicine, University of Virginia Health Sciences Center, Charlottesville, Virginia 22908
}

\begin{abstract}
The renal effects of angiotensin II(AII) are attributed to $\mathrm{AT}_{1}$ receptors. In contrast, the function of renal $\mathrm{AT}_{2}$ receptors is unknown. Using a microdialysis technique, we monitored changes in renal interstitial fluid (RIF) prostaglandin $\mathrm{E}_{2}\left(\mathrm{PGE}_{2}\right)$ and cyclic guanosine $3^{\prime}, 5^{\prime}$-monophosphate (cGMP) in response to dietary sodium $(\mathrm{Na})$ depletion alone, or $\mathrm{Na}$ depletion or normal $\mathrm{Na}$ diet combined with the $\mathrm{AT}_{1}$ receptor blocker, Losartan, the $\mathrm{AT}_{2}$ receptor blocker, $\mathrm{PD}$ 123319 (PD), or angiotensin II, individually or combined in conscious rats. $\mathrm{Na}$ depletion significantly increased $\mathrm{PGE}_{2}$ and cGMP. During Na depletion, Losartan decreased $\mathrm{PGE}_{2}$ and did not change cGMP. In contrast, PD significantly increased $\mathrm{PGE}_{2}$ and decreased cGMP. Combined administration of Losartan and PD decreased $\mathrm{PGE}_{2}$ and cGMP.

During normal Na diet, RIF $\mathrm{PGE}_{2}$ and cGMP increased in response to angiotensin II. Neither Losartan nor PD, individually or combined, changed RIF $\mathrm{PGE}_{2}$ or cGMP. Combined administration of angiotensin II and Losartan or PD produced a significant decrease in response of $\mathrm{PGE}_{2}$ and cGMP to angiotensin II, respectively.

These data demonstrate that activation of the reninangiotensin system during $\mathrm{Na}$ depletion increases renal interstitial $\mathrm{PGE}_{2}$ and $\mathrm{cGMP}$. The $\mathrm{AT}_{1}$ receptor mediates renal production of $\mathrm{PGE}_{2}$. The $\mathrm{AT}_{2}$ receptor mediates cGMP. $\mathrm{AT}_{2}$ blockade potentiates angiotensin-induced $\mathrm{PGE}_{2}$ production at the $\mathrm{AT}_{1}$ receptor. (J. Clin. Invest. 1996. 97:1978-1982.) Key words: extracellular space • kidney • sodium • Losartan - PD 123319
\end{abstract}

\section{Introduction}

The renin-angiotensin system plays an important role in body fluid volume, electrolyte balance, and arterial pressure (1). The mechanisms whereby these actions occur remain incompletely understood. The majority of studies suggest that the re-

Address correspondence to Helmy M. Siragy, M.D., Department of Medicine, Box 482, University of Virginia Health Sciences Center, Charlottesville, VA 22908. Phone: 804-924-5510. FAX: 804-982-3626. Received for publication 17 October 1995 and accepted in revised form 12 January 1996.

J. Clin. Invest.

(C) The American Society for Clinical Investigation, Inc. 0021-9738/96/04/1978/05 \$2.00

Volume 97, Number 8, April 1996, 1978-1982 nal actions of angiotensin II (AII) ${ }^{1}$ are mediated by angiotensin $\mathrm{AT}_{1}$ receptors (2). However, $\mathrm{AT}_{2}$ receptors also are present in the kidney (3) and have been reported recently to regulate pressure natriuresis in rats (4). The physiologic actions of $\mathrm{AII}$ at the $\mathrm{AT}_{2}$ receptor have been difficult to elicit, at least in part because $\mathrm{AT}_{2}$ receptors have a low degree of expression compared to that of $\mathrm{AT}_{1}$ receptors $(5,6)$.

We conducted the present study to investigate changes in renal interstitial fluid (RIF) cyclic GMP (cGMP) and prostaglandin $\mathrm{E}_{2}\left(\mathrm{PGE}_{2}\right)$ by renal interstitial fluid (RIF) microdialysis during sodium depletion, a condition which is known to stimulate the renin-angiotensin system (RAS), and during normal sodium diet, in response to angiotensin $\mathrm{AT}_{1}$ and $\mathrm{AT}_{2}$ receptor blockade in conscious rats. In this study, we utilized a novel microdialysis technique since it has several advantages over the traditional measurements conducted in blood or urine. First, repeated blood sampling in small animals may cause unwanted hemodynamic changes. Second, RIF sampling provides the ability to monitor in vivo chemical change at almost any site in an organ or tissue. Measurement of circulating hormones/autocoids may not reflect the local changes within that organ. Third, the concentration of chemical substances in the circulation may differ from that in the interstitium, which is closer to target receptors (7). Fourth, substances (e.g., kinins) can be formed and degraded in urine and do not reflect their concentrations within the target organ (8). Fifth, the molecular weight cutoff of the microdialysis membrane can function as an initial low-resolution step in discriminating between small and large molecules and help to exclude undesirable substances (degrading enzymes and carrier proteins). The isolation of free (unbound) materials can facilitate their bioanalytical measurement in a small volume without a need for complicated extraction procedures.

\section{Methods}

In vivo renal microdialysis technique. For the determination of renal interstitial fluid cGMP and $\mathrm{PGE}_{2}$, we constructed a microdialysis probe as previously described (7-9). Each end of single $0.5-\mathrm{cm}-$ long hollow fiber dialysis tubing $(0.1 \mathrm{~mm}$ inner diameter; molecular mass cutoff, 5000 D: Hospal, Meyzieu, France) was inserted into a manually dilated end of two 30-cm-long (inflow and outflow) hollow polyethylene tubes $(0.12 \mathrm{~mm}$ inner diameter, $0.65 \mathrm{~mm}$ outer diameter; Bioanalytical Systems, Indianapolis, IN). The distance between the ends of the polyethylene tubes was $3 \mathrm{~mm}$ (dialysis area) and the dial-

1. Abbreviations used in this paper: AII, angiotensin II; cGMP, cyclic guanosine $3^{\prime}, 5^{\prime}$-monophosphate; $\mathrm{PGE}_{2}$, prostaglandin $\mathrm{E}_{2}$; RIF, renal interstitial fluid. 
ysis fiber was sealed in place within the polyethylene tubes with cyanoacrylic glue, The dead volume of the dialysis tubing and outflow tube was $3.6 \mu \mathrm{l}$. The microdialysis probe was sterilized by a gas sterilization method.

In vitro microdialysis. In vitro recoveries of cGMP and $\mathrm{PGE}_{2}$ were evaluated by immersing dialysis membranes of ten different probes in a beaker containing $\left[{ }^{3} \mathrm{H}\right]$-cGMP or $\left[{ }^{3} \mathrm{H}\right]-\mathrm{PGE}_{2}(1,000,000$ $\mathrm{cpm} / \mathrm{ml}$ ). The inflow tube of each probe was connected to a gas-tight syringe filled with lactated Ringer's solution and perfused at 1, 2, 3 and $5 \mu \mathrm{l} / \mathrm{min}$ (pump 22, Harvard Apparatus, South Natick, MA), respectively. The effluent was collected from the outflow tube for 30min sample periods. The recovery of $\left[{ }^{3} \mathrm{H}\right]$-cGMP or $\mathrm{PGE}_{2}$ was calculated as percent ([cGMP or $\mathrm{PGE}_{2}$ in perfusate]/[cGMP or $\mathrm{PGE}_{2}$ in superfusate]). The best recovery rates were observed with a perfusion rate of $3 \mu \mathrm{l} / \mathrm{min}$ and were $70 \%$ for cGMP and $63 \%$ for $\mathrm{PGE}_{2}$, respectively.

To demonstrate that negligible amounts of cGMP or $\mathrm{PGE}_{2}$ stick to the polyethylene tubes of the dialysis probes, a known amount of $\left[{ }^{3} \mathrm{H}\right]$-cGMP or $-\mathrm{PGE}_{2}(1,000,000 \mathrm{cpm} / \mathrm{ml})$ was perfused through these tubes. The perfusate and dialysis tubing were counted in a Beta counter (Beckman Instruments, Fullerton, CA). The recoveries of $\left[{ }^{3} \mathrm{H}\right]$-cGMP and $-\mathrm{PGE}_{2}$ were 99.8 and $99.5 \%$, respectively.

Animal preparation. Experiments were conducted in six 4-wk-old female Sprague-Dawley rats purchased from Harlan Sprague-Dawley Inc. (Harlan Teklad, Madison, WI). With the rats under general anesthesia with $80 \mathrm{mg} / \mathrm{kg}$ ketamine intramuscularly (IM) (Aveco Company Inc., Fort Dodge, IA) and $8 \mathrm{mg} / \mathrm{kg}$ xylazine IM (Mobay Corp., Animal Health Div., Shawnee, KS), the right and left kidneys were exposed via a midline abdominal incision. The renal capsule of each kidney was penetrated with a 31-gauge needle that was tunneled in the outer renal cortex $\sim 1 \mathrm{~mm}$ from the outer renal surface for $0.5 \mathrm{~cm}$ before it exited by penetrating the capsule again. The tip of the needle was inserted into one end of the dialysis probe and the needle was pulled together with the dialysis tube until the dialysis fiber was situated in the renal cortex. The inflow and outflow tubes of dialysis probes were tunneled subcutaneously through a bevel-tipped stainless steel tube and exteriorized near the interscapular region. To obtain vascular access, a heparinized polyethylene tube (PE 50) was inserted into the right carotid artery. This tube was flushed daily with $10 \%$ heparin in $\mathrm{D}_{5} \mathrm{~W}$ and capped with a small piece of copper wire. Exterior ends of these tubes were secured in place by suturing them to skin at exit site. The exteriorized portions of the tubes were placed in a stainless steel spring to prevent rats from damaging them. Rats were allowed 7-d for recovery and to acclimatize to the laboratory. Rats were housed under controlled conditions (temperature $21 \pm 1^{\circ} \mathrm{C}$; humidity: $60 \pm 10 \%$; lighting: $8-20 \mathrm{~h}$ ). Experiments were started at the same time ( $8 \mathrm{AM})$ each day to avoid any diurnal variation of the measured substances. For collection of renal interstitial fluid (RIF), the inflow tube was connected to a gas-tight syringe filled with lactated Ringer's solution and perfused at $3 \mu \mathrm{l} / \mathrm{min}$. The effluent was collected from the outflow tube for 30-min sample periods in nonheparinized plastic tubes and stored at $-80^{\circ} \mathrm{C}$ until assayed for cGMP and $\mathrm{PGE}_{2}$.

Analytical methods. Urinary sodium levels were measured by a NOVA analyzer (NOVA Biomedical, Waltham, MA). Renal interstitial fluid $\mathrm{PGE}_{2}$ and cGMP levels in dialysate samples were measured by radioimmunoassay (RIA) (9-11). The sensitivity and specificity of the RIA for $\mathrm{PGE}_{2}$ were $114 \mathrm{pg} / \mathrm{ml}$ and $100 \%$, respectively; and for cGMP were $0.11 \mathrm{pmol} / \mathrm{ml}$ and $100 \%$, respectively. The intra- and interassay coefficient of variation was $<10 \%$ for both assays. Cross reactivity of the $\mathrm{PGE}_{2}$ assay with other eicosanoids was $<0.01 \%$ and of the cGMP assay was $<0.01 \%$ with other cyclic nucleotides.

Effects of sodium depletion and angiotensin $A T_{1}$ and $A T_{2}$ receptor blockade on RIF cGMP and PGE . In this study, rats $(n=6)$ were placed in metabolic cages. A baseline $24 \mathrm{~h}$ urine collection was obtained for calculation of urine flow rate $(\mathrm{V})$ and sodium excretion $\left(\mathrm{U}_{\mathrm{Na}} \mathrm{V}\right)$ and RIF samples were obtained for cGMP and $\mathrm{PGE}_{2}$ (experimental day 1$)$ while rats were consuming normal sodium diet $(0.28 \%$
$\mathrm{NaCl}$, Bioserve, Frenchtown, $\mathrm{NJ})$. Then rats were placed on a low sodium diet $(0.15 \% \mathrm{NaCl})$ for $7 \mathrm{~d}$. We continued to monitor $24 \mathrm{~h} \mathrm{~V}$ and $\mathrm{U}_{\mathrm{Na}} \mathrm{V}$ and RIF cGMP and $\mathrm{PGE}_{2}$ daily for $4 \mathrm{~d}$ (experimental days 2-5). While rats continued to consume the low sodium diet (days 6-8) RIF cGMP and $\mathrm{PGE}_{2}$ were monitored during the right intracarotid administration in random order of (1) $5 \%$ dextrose in water (D5W), (2) Losartan (DuPont Pharmaceutical Co., Wilmington, DE), a long acting non-peptide angiotensin II antagonist at $\mathrm{AT}_{1}$ receptors $\left(\mathrm{IC}_{50} 3 \times\right.$ $10^{-4}$ and $7 \times 10^{-9} \mathrm{M}$ for $\mathrm{AT}_{2}$ and $\mathrm{AT}_{1}$ receptors, respectively) $(2,4)$, or (3) PD 123319 (Parke-Davis, Ann Arbor, MI), a specific $\mathrm{AT}_{2}$ receptor antagonist $\left(\mathrm{IC}_{50} 2 \times 10^{-8} \mathrm{M}\right.$ and above $1 \times 10^{-4} \mathrm{M}$ for $\mathrm{AT}_{2}$ and $\mathrm{AT}_{1}$ receptors, respectively) $(4,12)$. Losartan $10 \mathrm{mg} / \mathrm{kg}$ was given 30 min before the experiment, which produces plasma concentrations near $6 \times 10^{-5} \mathrm{M}(2,3)$. PD 123319 was infused at $50 \mu \mathrm{g} / \mathrm{kg}$ per min, which yields plasma concentrations near $3 \times 10^{-6} \mathrm{M}$, a value which remains highly specific for $\mathrm{AT}_{2}$ receptors $(2,3)$. Mean arterial pressure (MAP) was measured every $10 \mathrm{~min}$ in the rat tail (Rat Tail Monometer-Tachometer System, Natsume Model KN-210, Peninsula Laboratories, Belmont, CA) and the recorded values were averaged for each study period. The study was repeated during PD 123319 infusion $(50 \mu \mathrm{g} / \mathrm{kg}$ per min) which started $30 \mathrm{~min}$ after Losartan administration $(10 \mathrm{mg} / \mathrm{kg})$.

Effects of angiotensin $A T_{1}$ and $A T_{2}$ receptor blockade on urinary flow rate and sodium excretion. The above study was repeated acutely in rats $(n=6)$ under anesthesia except that dialysis probes were not inserted into the kidneys. Urine was collected from urinary bladder catheters during intracarotid infusion in random order of D5W, Losartan or PD 123319 to monitor changes in $\mathrm{V}$ and $\mathrm{U}_{\mathrm{Na}} \mathrm{V}$.

Effects of angiotensin $A T_{1}$ and $A T_{2}$ receptor blockade on RIF cGMP and $P G E_{2}$ during normal sodium intake. To evaluate if the observed changes in RIF cGMP and $\mathrm{PGE}_{2}$ during $\mathrm{AT}_{1}$ and $\mathrm{AT}_{2}$ blockade were related to changes in renal AII during sodium depletion, we repeated the above study (days $6-8)$ after rats $(n=6)$ were placed on a normal sodium diet for $5 \mathrm{~d}$. RIF cGMP and $\mathrm{PGE}_{2}$ were monitored during a control period (D5W was infused into right carotid artery at $20 \mu \mathrm{l} / \mathrm{min}$ for $30 \mathrm{~min}$ ), and during a treatment period (30 min) during which (1) D5W (20 $\mu \mathrm{l} / \mathrm{min})$, (2) AII (30 ng/kg/min), (3) Losartan (10 mg/kg), or (4) PD $123319(50 \mu \mathrm{g} / \mathrm{kg}$ per min) individually or combined were administered intravenously. The dose of AII was determined from a dose-pressor response curve for AII. We chose the largest dose of AII which did not elicit any rise in blood pressure.

Statistical analysis of data. Comparisons among pharmacologic agents and controls were examined by analysis of variance (ANOVA) including a repeated measures term, using the General Linear Models procedure (13) of the Statistical Analysis System. Multiple comparisons of individual pairs of effect means were conducted by use of values of least-square means pooled variance. Data are expressed as mean $\pm 1 \mathrm{SE}$. Statistical significance was identified at $P<0.05$.

\section{Results}

Mean arterial pressure responses to Losartan, PD, or AII individually or combined. During low sodium intake Losartan decreased MAP from $118 \pm 2$ to $109 \pm 2 \mathrm{mmHg}(P<0.05)$. There were no significant changes in MAP during administration of PD alone or combined with Losartan. During normal sodium intake there were no significant changes in MAP associated with AII, Losartan or PD infused individually or combined.

Renal responses to Losartan or PD during low sodium intake in anesthetized rats $(n=6)$. During D5W infusion (control period) $\mathrm{V}$ (Fig. $1 A$ ) was $3.4 \pm 0.1 \mu \mathrm{l} / \mathrm{min}$ and increased to $8.5 \pm 0.2 \mu \mathrm{l} / \mathrm{min}$ in response to Losartan administration $(P<$ 0.0001). Similarly, $\mathrm{U}_{\mathrm{Na}} \mathrm{V}$ (Fig. $1 B$ ) increased significantly from $0.078 \pm 0.004$ to $0.232 \pm 0.020 \mu \mathrm{eq} / \mathrm{min}(P<0.0001)$ in response 

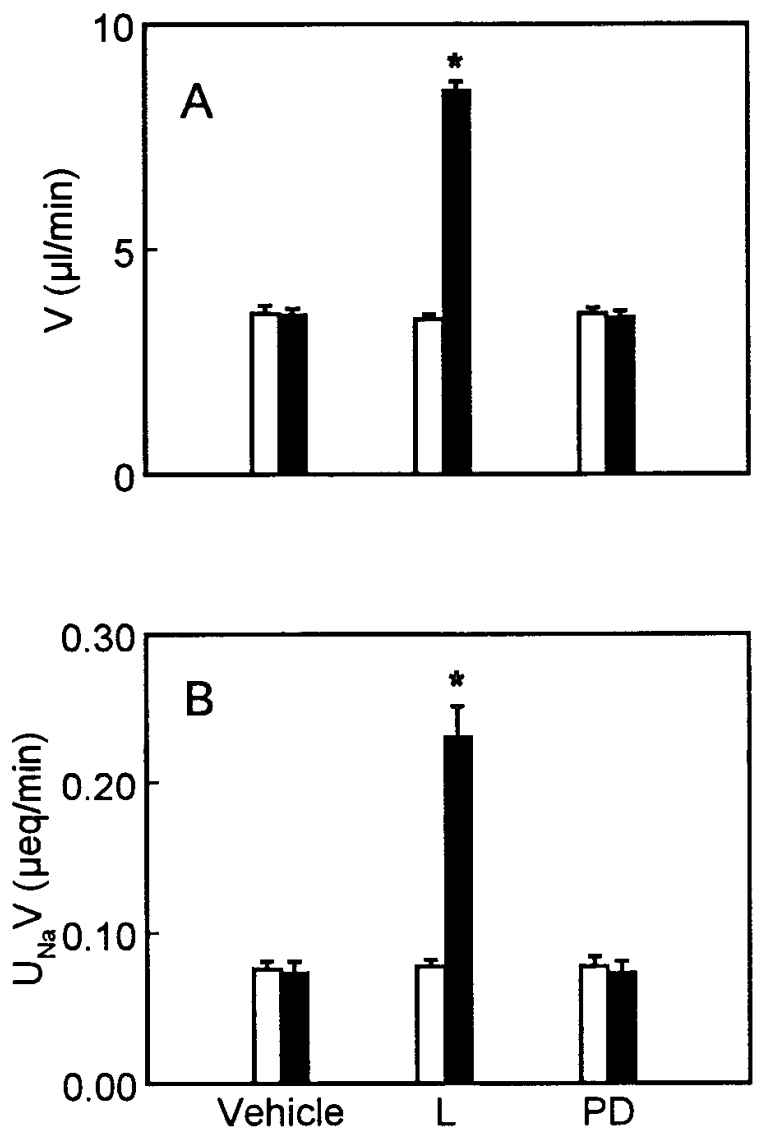

Figure 1. Urinary flow rate $(\mathrm{V})(A)$ and urinary sodium excretion $\left(\mathrm{U}_{\mathrm{Na}} \mathrm{V}\right)(B)$ during i.v. infusion of vehicle, Losartan $(\mathrm{L})(10 \mathrm{mg} / \mathrm{kg})$ or PD 123319 (PD) $(50 \mu \mathrm{g} / \mathrm{kg}$ per min). Experimental data are shown in solid bars and time control data in open bars for anesthetized rats $(n=6)$ at the end of $5 \mathrm{~d}$ of dietary sodium depletion. ${ }^{*} P<0.0001$ compared with vehicle or time control.

to Losartan. There were no significant changes in $\mathrm{V}$ or $\mathrm{U}_{\mathrm{Na}} \mathrm{V}$ in response to $\mathrm{PD}$ administration.

RIF cGMP and PGE $E_{2}$ responses to dietary sodium depletion, $P D$ or Losartan in conscious rats $(n=6)$. A progressive reduction in 24-h $\mathrm{U}_{\mathrm{Na}} \mathrm{V}$ was observed during a low sodium intake. 24-h urinary sodium excretion decreased from $605 \pm 34 \mu \mathrm{mol} / \mathrm{d}$ during a normal sodium diet to $328 \pm 22,73 \pm 11,35 \pm 13,30 \pm 11$, and $30 \pm 10 \mu \mathrm{mol} / \mathrm{d}$ during days 1 through 5 of the low sodium intake, respectively. RIF PGE $\mathrm{P}_{2}$ and cGMP levels (Fig. 2) increased significantly and progressively during dietary sodium depletion. RIF PGE 2 (Fig. $2 A$ ) and cGMP (Fig. $2 B$ ) increased by $\sim 3.1$ - and 2.7-fold respectively, by the fifth day of sodium depletion. At the end of the fifth day of sodium depletion, RIF $\mathrm{PGE}_{2}$ decreased significantly in response to Losartan administration $(P<0.001)$, while RIF $\mathrm{PGE}_{2}$ increased during PD infusion $(P<0.001)$. RIF cGMP (Fig. $2 B)$ did not change in response to Losartan, but decreased to levels observed during normal sodium intake in response to PD $(P<0.001)$. Combined infusion of Losartan and PD significantly decreased both RIF cGMP and $\mathrm{PGE}_{2}$ to the levels observed during normal sodium diet $(P<0.001)$.

RIF cGMP and PGE responses to AII, Losartan or PD during normal sodium intake in conscious rats $(n=6)$. RIF $\mathrm{PGE}_{2}$ (Fig. $3 A$ ) and cGMP (Fig. $3 B$ ) increased during AII infusion
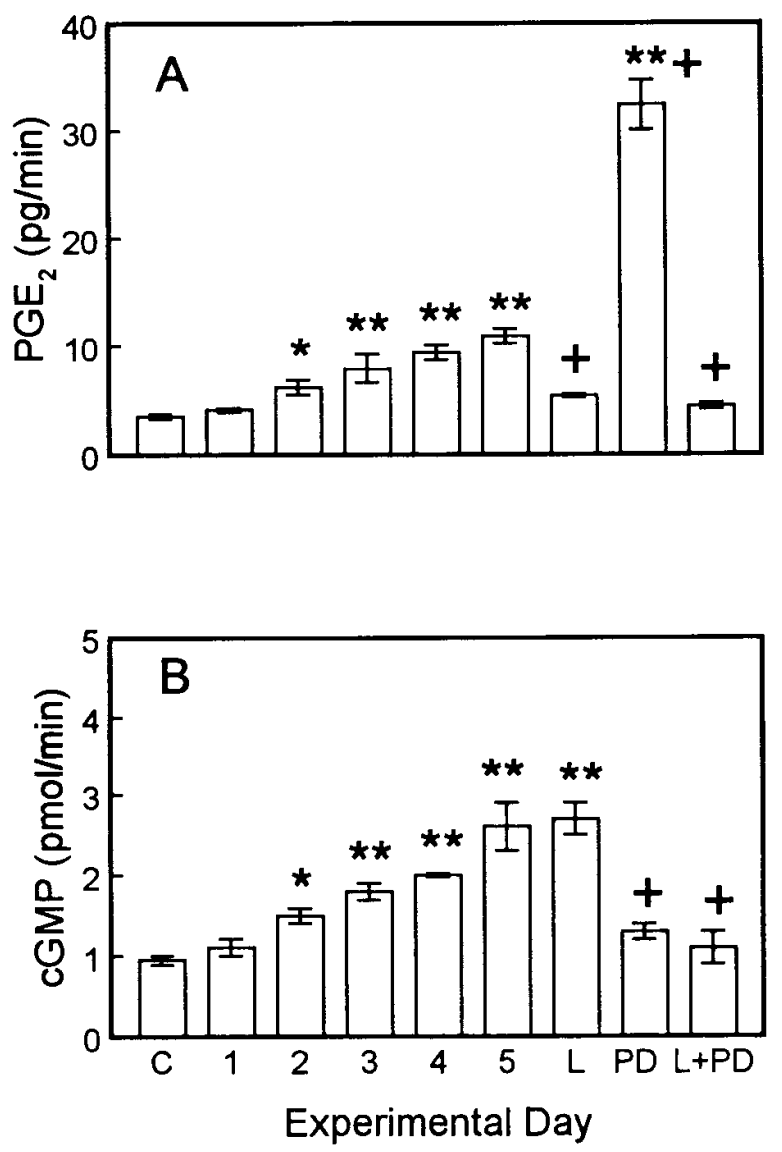

Figure 2. Renal interstitial fluid prostaglandin- $\mathrm{E}_{2}\left(\mathrm{PGE}_{2}\right)(A)$ and cyclic guanosine $3^{\prime}, 5^{\prime}$-monophosphatae (cGMP) $(B)$ in response to 5 days of dietary sodium depletion alone, or sodium depletion combined with i.v. infusion of Losartan (L) (10 mg/kg) or PD 123319 (PD) $(50 \mu \mathrm{g} / \mathrm{kg} / \mathrm{min})$ individually or combined in conscious rats $(n=$ 6). $* P<0.001, * * P<0.0001$ compared with control $(C)$ values obtained which were obtained during normal dietary sodium intake ${ }^{\dagger} P<$ 0.001 compared with day 5 of dietary sodium depletion.

from $2.9 \pm 0.07$ to $6.1 \pm 0.1 \mathrm{pg} / \mathrm{min}$ and $1.2 \pm 0.06$ to $1.6 \pm 0.1$ $\mathrm{pmol} / \mathrm{min}$, respectively $(P<0.001)$. Losartan or PD, individually or combined, did not change RIF $\mathrm{PGE}_{2}$ (Fig. $3 A$ ) or RIF cGMP (Fig. $3 \mathrm{~B}$ ). Combined administration of AII and Losartan decreased the RIF $\mathrm{PGE}_{2}$ response to AII from $6.2 \pm 0.1$ to $3.8 \pm 0.08 \mathrm{pg} / \mathrm{min}$, but did not change the cGMP response to AII. Combined AII and PD (Fig. $3 \mathrm{~B}$ ) blocked the cGMP response to AII $(0.9 \pm 0.08$ vs. $1.6 \pm 0.1 \mathrm{pmol} / \mathrm{min})(P<0.01)$ and significantly increased the $\mathrm{PGE}_{2}$ (Fig. $3 A$ ) response to AII from $3.0 \pm 0.1$ to $10.2 \pm 0.4 \mathrm{pg} / \mathrm{min}(P<0.001)$. Simultaneous administration of AII, Losartan and PD blunted both the RIF cGMP and $\mathrm{PGE}_{2}$ responses to AII $(P<0.001)$.

\section{Discussion}

This study demonstrates clearly, to our knowledge for the first time, a physiological function for the renal subtype- 2 angiotensin $\left(\mathrm{AT}_{2}\right)$ receptor in the rat. The $\mathrm{AT}_{2}$ receptor antagonist, PD 123319 (PD), blocked the increase in RIF cyclic guanosine 3', 5' monophosphate (GMP) engendered by dietary sodium depletion or by AII administration during normal sodium intake. Our data suggest that the renal $\mathrm{AT}_{2}$ receptor is tonically 

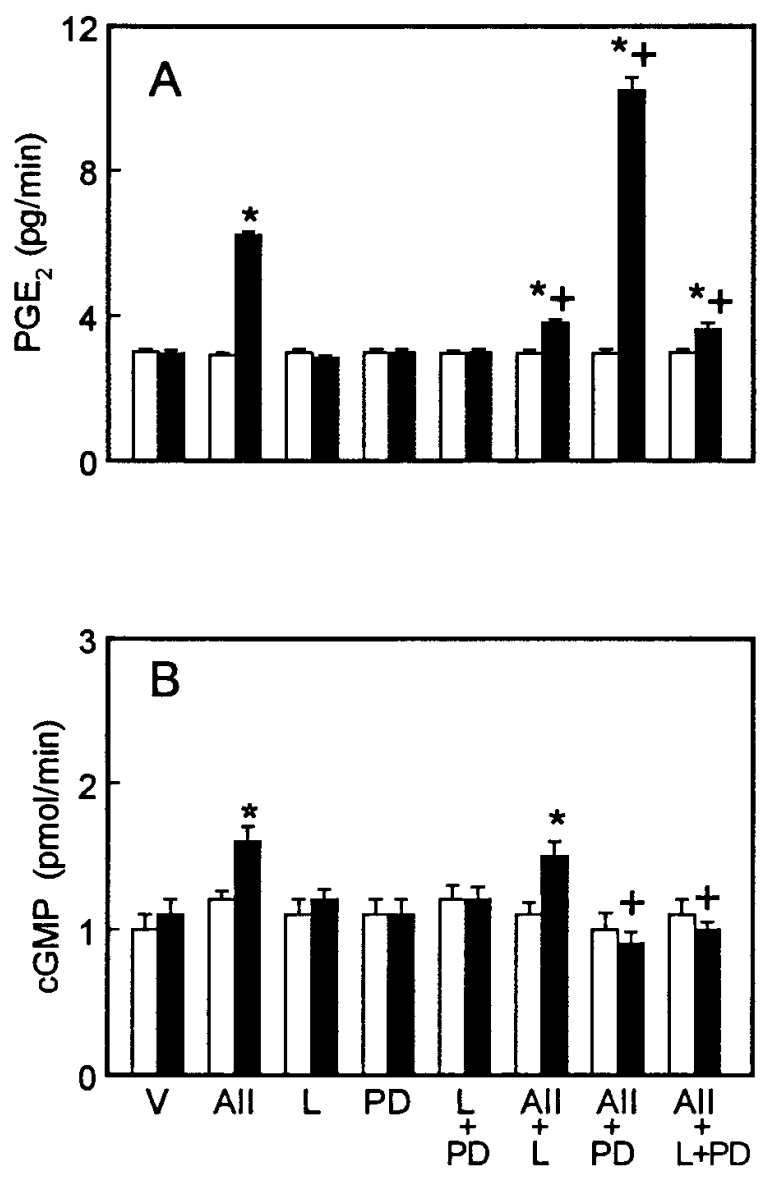

Figure 3. Renal interstitial fluid prostaglandin- $\mathrm{E}_{2}\left(\mathrm{PGE}_{2}\right)(A)$ and cyclic guanosine $3^{\prime}, 5^{\prime}$-monophosphatae (cGMP) $(B)$ during i.v. infusion of vehicle (V), Losartan (L) (10 mg/kg), PD 123319 (PD) $(50 \mu \mathrm{g} /$ $\mathrm{kg}$ per $\mathrm{min}$ ), or angiotensin II (AII) (30 $\mathrm{ng} / \mathrm{kg} / \mathrm{min})$, individually or combined in conscious rats $(n=6)$ on normal dietary sodium intake. Experimental data are shown in solid bars and time control data in open bars. ${ }^{*} P<0.001$ compared with vehicle (V) or time control. ${ }^{+} P<$ 0.001 compared with angiotensin II (AII) alone.

stimulated to effect a release of cyclic GMP in response to a physiologic stimulus, sodium depletion.

We have shown that sodium depletion is associated with a substantial increase in RIF AII concentrations (9) and it is highly likely that the progressive increase in RIF cyclic GMP was related to augmented AII formation. This thesis is strengthened by our observations that exogenous AII increased RIF cyclic GMP during normal sodium intake. Cyclic GMP mediates the effects of nitric oxide, the endotheliumderived vascular relaxing factor, and has been shown to be released from the renal vascular smooth muscle cell (14). AII releases nitric oxide (15), which activates guanylyl cyclase, and releases cyclic GMP into the RIF. This action of AII is mediated at the $\mathrm{AT}_{2}$ receptor, according to our data. It is highly unlikely that cyclic GMP is modulated via the $\mathrm{AT}_{1}$ receptor because the $\mathrm{AT}_{1}$ antagonist, Losartan, did not affect cyclic GMP and the combination of Losartan and PD resulted in a similar reduction of cyclic GMP as did PD alone.

The infusion rate of PD employed in the present study has been shown to be specific for the $\mathrm{AT}_{2}$ receptor and not to interact with the $\mathrm{AT}_{1}$ receptor $(2,4,12)$. Other studies using markedly higher doses of PD have demonstrated increased urine volume or free water formation $(16,17)$ in anesthetized animals, but PD may have influenced other (non- $\mathrm{AT}_{2}$ ) angiotensin receptors in these studies. Recently, using a similar infusion rate of $\mathrm{PD}$ as in the present study, $\mathrm{AT}_{2}$ receptors were found to regulate pressure natriuresis in anesthetized rats (4). The results of the present study provide a potential mechanism for this observation.

The present study also demonstrates unequivocally that AII stimulates prostaglandin $\mathrm{E}_{2}\left(\mathrm{PGE}_{2}\right)$ by an action at the $\mathrm{AT}_{1}$ receptor. Losartan blocked the increase in $\mathrm{PGE}_{2}$ resulting from both sodium depletion and AII administration. However, we were surprised to find that RIF $\mathrm{PGE}_{2}$ rose approximately threefold in response to $\mathrm{AT}_{2}$ receptor blockade with $\mathrm{PD}$ in the presence of sodium depletion. This increase in $\mathrm{PGE}_{2}$ was due to an action of AII at the $\mathrm{AT}_{1}$ receptor because the combination of PD and Losartan abrogated the response completely. It is unlikely that $\mathrm{PD}$ decreased $\mathrm{PGE}_{2}$ uptake, degradation or clearance. However, it is possible that decreased nitric oxide/ cyclic GMP production may have contributed to the increase in $\mathrm{PGE}_{2}$ production in response to $\mathrm{PD}$. This is in contrast to the interaction between $\mathrm{NO}$ and prostaglandin production in renal inflammation model (18) in which NO has been reported to stimulate $\mathrm{PGE}_{2}$ release. We interpret our results as indicating that during sodium depletion $\mathrm{PGE}_{2}$ formation is tonically stimulated by AII at the $\mathrm{AT}_{1}$ receptor. Our data show that in the presence of $\mathrm{AT}_{2}$ receptor blockade, there is a shift of AII action to the $\mathrm{AT}_{1}$ receptor to enhance $\mathrm{PGE}_{2}$ production. These observations suggest that the renal $\mathrm{AT}_{2}$ receptor may participate in a negative feedback loop whereby AII acts physiologically at the $\mathrm{AT}_{2}$ receptor to decrease renal AII formation. When this mechanism is unmasked by $\mathrm{AT}_{2}$ blockade, an increase in AII would result in a marked enhancement of $\mathrm{PGE}_{2}$ formation. Other possible mechanisms that could account for the observed increase in RIF $\mathrm{PGE}_{2}$ during $\mathrm{AT}_{2}$ receptor blockade include: (1) Decreased activity of PGE 9-ketoreductase, the enzyme responsible for converting $\mathrm{PGE}_{2}$ to $\mathrm{PGF}_{2 \alpha}$. This enzyme may be stimulated by bradykinin and/or AII $(19,20)$ during sodium depletion $(7,9)$. We hypothesize that PGE 9-ketoreductase could be inhibited during $\mathrm{AT}_{2}$ receptor blockade resulting in the observed marked increase in $\mathrm{PGE}_{2}$ levels. (2) Decreased cGMP in response to $\mathrm{AT}_{2}$ blockade could increase the cGMP-inhibitable isoform of cAMP phosphodiestrase (PDE III), resulting in diminished renal cAMP levels (21). The latter would promote prostaglandin formation, as cAMP has been shown to inhibit cyclooxygenase activity $(22,23)$. In the present study we were limited by the volume of interstitial fluid sample collected and could not measure $\mathrm{PGF}_{2} \alpha$ or cAMP. Further studies are needed to address whether renal AII concentrations are increased by PD. Receptor interaction, such as suggested here, may constitute an important physiologic principle in the paracrine control of renal function.

The majority of past studies have failed to demonstrate a function for the renal $\mathrm{AT}_{2}$ receptor, but these studies were conducted during normal sodium intake. Our study confirms that renal responses (i.e., $\mathrm{PGE}_{2}$ and cyclic GMP) to $\mathrm{AT}_{1}$ and $\mathrm{AT}_{2}$ receptor blockade are absent during normal sodium intake. Therefore, the physiological effects of angiotensin on the kidney are reserved for situations, such as sodium depletion, in which the RAS is chronically stimulated. Whether or not renal $\mathrm{AT}_{2}$ receptor messenger RNA or protein expression are en- 
hanced by sodium depletion has not been studied to our knowledge.

The question of whether the changes in RIF cyclic GMP stimulated by AII are significant in the control of renal hemodynamic/tubular function awaits further study. Our data in anesthetized sodium depleted rats, reported here, show an increase in sodium and water excretion with Losartan but not with PD. However, since the expression of renal $\mathrm{AT}_{2}$ receptors (compared to $\mathrm{AT}_{1}$ ) is low, the high levels of angiotensin II formed during anesthesia (24) should stimulate $\mathrm{AT}_{1}$ receptors and overwhelm the effects of $\mathrm{AT}_{2}$ receptors on sodium excretion. Thus, the effects of PD on sodium excretion may be different in conscious animals. In the present study, it was technically impossible to measure urinary sodium excretion every 30 min in conscious rats, but we were able to monitor changes in RIF $\mathrm{PGE}_{2}$ and cGMP in response to PD. It is possible that intrarenal vasodilation initiated by $\mathrm{PD}$ and increased $\mathrm{PGE}_{2}$ formation is counter balanced by decreased nitric oxide/cyclic GMP. Further studies are needed in a conscious animal model in which renal function can be carefully monitored.

In conclusion, we have shown that activation of the reninangiotensin system during sodium depletion in rats increases renal interstitial fluid levels of $\mathrm{PGE}_{2}$ and cGMP which are mediated by $\mathrm{AT}_{1}$ and $\mathrm{AT}_{2}$ receptors, respectively. Furthermore, the $\mathrm{AT}_{2}$ receptor modulates $\mathrm{PGE}_{2}$ production by angiotensin $\mathrm{II}$ at the $\mathrm{AT}_{1}$ receptor.

\section{Acknowledgments}

This work was supported by grants HL-4766229 (H.M. Siragy and HL-49575 (R.M. Carey) from the National Institutes of Health. Dr. Siragy is the recipient of Research Career Development Award K04 HL-03006 from the National Institutes of Health.

\section{References}

1. Navar, L.G., and L. Rosival. 1984. Contribution of the renin-angiotensin system to the control of intrarenal hemodynamics. Kidney Int. 25:857-868.

2. Macari, D., S. Bottani, S. Whitebread, M. De Gasparo, and N. Levens. 1993. Renal actions of the selective angiotensin $\mathrm{AT}_{2}$ receptor ligands CGP 42112 B and PD 123319 in the sodium-depleted rat Eur. J. Pharmacol. 249:8593.

3. Ernsberger, P., J. Zhou, T. Damon, and J.G. Douglas. 1992. Angiotensin II receptor subtypes in cultured rat renal mesangial cells. Am. J. Physiol. 263: F411-F416.

4. Lo, M., K. Liu, P. Lantelme, and J. Sassard. 1995. Subtype 2 of angio- tensin II receptors controls pressure-natriuresis in rats. J. Clin. Invest. 95:1394-1394.

5. Zhuo, J., K. Song, P.J. Harris, and F.A.O. Mendelsohn. 1992. In vitro autoradiography reveals predominantly $\mathrm{AT}_{1}$ angiotensin II receptors in rat kidney. Renal Physiol. Biochem. 15:231-239.

6. Zhuo, J., D. Alcorn, P.J. Harris, and F.A.O. Mendelsohn. 1993. Localization and properties of angiotensin II receptors in rat kidney. Kidney Int. 44(Suppl 42):S40-S46.

7. Siragy, H.M., N.L. Howell, N.V. Ragsdale, and R.M. Carey. 1995. Renal interstitial fluid angiotensin modulation by anesthesia, epinephrine, sodium depletion, and renin inhibitor. Hypertension. 25:1021-1024.

8. Siragy, H.M., M.M. Ibrahim, A.A. Jaffa, R. Mayfield, and H.S. Margolius. 1994. Rat renal interstitial bradykinin, prostaglandin $\mathrm{E}_{2}$, and cyclic guanosine 3', 5'-monophosphate. Effects of altered sodium intake. Hypertension. 23:1068-1070.

9. Siragy, H.M., A.A. Jaffa, and H.S. Margolius. 1993. Stimulation of renal interstitial bradykinin by sodium depletion. Am J. Hypertens. 6:863-866.

10. Harper, J.F., and G. Brooker. 1975. Femtomole sensitive radioimmunoassay for cyclic AMP and cyclic GMP after 2'0 acetylation by acetic anhydride in aqueous solution. J. Cyclic Nucl. Res. 1:207-218.

11. Powell, W.S. 1980. Rapid extraction of oxygenated metabolites of arachidonic acid from biological samples using octadecysilyl silica. Prostaglandin. 20:947-957.

12. Dudley, D.T., R.L. Panek, T.C. Major, G.H. Lu, R.F. Bruns, B.A. Klinkefus, J.C. Hodges, and R.E. Weishaar. 1990. Subclasses of angiotensin II binding sites and their functional significance. Mol. Pharmacol. 38:370-377.

13. Goodnight, J.H., and W.R. Harvey. 1978. Least square Means in the fixed effects general linear model. SAS Institute; SAS technical report, Cary, NC. R-103.

14. Chevalier, R.L., R.J. Fern, M. Garmey, S.S. el-Dahr, R.A. Gomez, and J. DeVente. 1992. Localization of cGMP after infusion of ANP or nitroprusside in the maturing rat. Am. J. Physiol. 262:F417-F424.

15. Moncada, S., R.M. Palmer, and E.A. Higgs. 1991. Nitric oxide: physiology, pathophysiology, and pharmacology. Pharmacol. Rev. 43:109-142.

16. Kaiser, J.A., F.A. Bjork, J.C. Hodges, and D.G. Taylor, Jr. 1992. Renal hemodynamic and excretory responses to PD 123319 and losartan, nonpeptide $\mathrm{AT}_{1}$ and $\mathrm{AT}_{2}$ subtype-specific angiotensin II ligands. J. Pharmacol. Exp. Ther. 262:1154-1160.

17. Clark, K.L., M.J. Robertson, and G. Michael Drew. 1993. Role of angiotensin $\mathrm{AT}_{1}$ and $\mathrm{AT}_{2}$ receptors in mediating the renal effects of angiotensin $\mathrm{II}$ in the anesthetized dogs. Br. J. Pharmacol. 109:148-156.

18. Salvemini, D., K. Seibert, J.L. Masferrer, T.P. Misko, M.G. Currie, and P. Needleman. 1994. Endogenous nitric oxide enhances prostaglandin production in a model of renal inflammation. J. Clin. Invest. 93:1940-1947.

19. Wong, P.Y., D.A. Terragno, N.A. Terragno, and N.C. McGiff. 1977. Dual effects of bradykinin on prostaglandin metabolism: relationship to the dissimilar vascular actions of kinins. Prostaglandins. 13:1113-1125.

20. Weber, P.C., C. Larsson, B. Scherer. 1977. Prostaglandin $E_{2}-9$-ketoreductase as a mediator of salt intake-related prostaglandin-renin interaction. $\mathrm{Na}$ ture (Lond.). 266:65-66.

21. Sonnenburg, W.K., and J.A. Beavo. 1994. Cyclic GMP and regulation of cyclic nucleotide hydrolysis. Adv. Pharmacol. 26:87-114.

22. Hopkins, N.K., and R.R. Gorman. 1981. Regulation of cell cyclic nucleotide metabolism by prostacyclin J. Clin. Invest. 67:540-546.

23. Lim, L.K., N.H. Hunt, R.D. Eichner, and M.J. Weidemann. 1983. Cyclic AMP and the regulation of prostaglandin production by macrophages. Biochem. Biophys. Res. Comm. 114:248-254.

24. Johnson, M.D., and R.L. Malvin. 1975. Plasma renin activity, pentobarbital anesthesia and graded hemorrhage in dogs. Am. J. Physiol. 229:1098-1101. 